\title{
Accuracy of Advanced Methods for Nonlinear Static Analysis of Steel Moment-Resisting Frames
}

\author{
Massimiliano Ferraioli, Alberto M. Avossa, Angelo Lavino and Alberto Mandara*
}

Department of Civil Engineering, Design, Building and Environment, Second University of Naples, via Roma 9, 81031, Aversa (CE), Italy

\begin{abstract}
The reliability of advanced nonlinear static procedures to estimate deformation demands of steel momentresisting frames under seismic loads is investigated. The advantages of refined adaptive and multimodal pushover procedures over conventional methods based on invariant lateral load patterns are evaluated. In particular, their computational attractiveness and capability of providing satisfactory predictions of seismic demands in comparison with those obtained by conventional force-based methods are examined. The results obtained by the static advanced methods, used in the form of different variants of the original Capacity Spectrum Method and Modal Pushover Analysis, are compared with the results of nonlinear response history analysis. Both effectiveness and accuracy of these approximated methods are verified through an extensive comparative study involving both regular and irregular steel moment resisting frames subjected to different acceleration records.
\end{abstract}

Keywords: Adaptive capacity spectrum method, Modal pushover, Nonlinear analysis, Steel moment resisting frames.

\section{INTRODUCTION}

The estimation of lateral displacement demands is of primary importance in performance-based earthquakeresistant design. In fact, both structural and non-structural damage are primarily related to lateral displacements. However, estimating seismic demands at high performance levels, such as life safety and collapse prevention, requires explicit consideration of the inelastic behaviour of the structure. While nonlinear response history analysis (RHA) is the most rigorous procedure to estimate seismic demands, static pushover analysis is extensively employed to determine the deformation demands with acceptable accuracy without the complex modelling and computational effort of RHA. In general, applying displacement rather than force loading in pushover procedures would be the most suitable option for nonlinear static analysis of structures subjected to earthquake ground motion. However, due to the unvarying nature of the applied displacement loading vector, this approach may neglect the strong variations of the displacement pattern that may occur during the mechanism of failure after yielding as a result of strength irregularities and soft storeys. Consequently, when an invariant load pattern is used, the forcebased pushover is to be preferred to displacement-based pushover. However, the accuracy of these conventional force-based pushover analyses in predicting seismic demands of structures and their limitations especially for highrise buildings remain among the most controversial topics. The traditional pushover analysis with an invariant lateral force pattern, in fact, accurately estimates the seismic

\footnotetext{
*Address correspondence to this author at the Department of Civil Engineering, Design, Building and Environment, Second University of Naples, via Roma 9, 81031, Aversa (CE), Italy; Tel: +39081 5010216;

Fax:+39081 5037370; E-mail: alberto.mandara@unina2.it
}

response of low-rise and regular buildings, where the response is dominated by the first mode and the development of a collapse mechanism of the global type is possible. On the contrary, significant differences have been found in highrise buildings where the effects of the higher modes cannot be neglected and undesired collapse mechanism typologies may be developed. In particular, high rise buildings are more prone to develop partial mechanisms involving a limited number of storeys compared to the total number. The occurrence of such storey mechanism confirms the importance of design procedures focusing on plastic mechanism control of MR-frames [1-5]. The two major weaknesses of the conventional pushover methods are: 1) the higher mode effects are neglected; 2) the changes in the dynamic properties of the structures and, consequently, in the loading pattern are ignored. This is mainly due to the fact that inertia force distribution changes continuously under earthquake ground motion due to higher mode contribution and stiffness degradation. In order to overcome these drawbacks, some researchers have proposed invariant loading patterns taking into account the higher mode effects. Other researchers have developed adaptive pushover procedures accounting for higher mode effects and progressive damage accumulation. In this way, they intended to overcome the most important limitations of traditional methods especially for estimating seismic demands of tall buildings. However, some of these nonlinear static procedures require very complex analyses and, consequently, they fail the target of using procedures simpler than nonlinear time-history methods. Nevertheless, these adaptive pushover methods may represent an attractive displacementbased tool for structural assessment, fully complying with the recently introduced deformation and performance oriented trends in the field of earthquake engineering. 


\section{CURRENT NONLINEAR STATIC PROCEDURES IN SEISMIC CODES}

Both validity and applicability of the static pushover analysis have been extensively studied in literature. Some Nonlinear Static Procedures (NSPs) have been incorporated in the new generation of seismic codes to determine the deformation demand imposed on buildings which are expected to behave inelastically. Generally, these NSPs are implemented in procedures based on Capacity Spectrum Method (CSM) or Displacement Coefficient Method (DCM), such as in FEMA 273 [6], ATC-40 [7], FEMA 356 [8], Eurocode 8 [9], Italian Code [10], FEMA-440 (ATC-55) [11], ASCE/SEI 41-06 Standard [12]. In particular, ATC-40 Report proposes three nonlinear static procedures based on $\mathrm{Ca}$ pacity Spectrum Method (CSM). As an alternative, the Coefficient Method (CM) of FEMA-356 is based on a displacement modification procedure in which several empirically derived factors are used to modify the response of a linearlyelastic, SDOF (single-degree-of-freedom) model with an equivalent damping related to the hysteretic behaviour of the structure. However, several deficiencies can be found in such methods. In particular, no physical principle justifies the existence of a stable relationship between hysteretic energy dissipation and equivalent viscous damping, particularly for highly inelastic systems. As a consequence, procedures based on the High Damping Elastic Demand Response Spectra (HDERS), such as ATC 40 and FEMA 440 (ATC-55), may give an unreliable estimation of the target displacement when compared with time-history analysis. Furthermore, in some documents an invariant lateral load distribution is considered for pushover analysis. This assumption may be very unrealistic for structures where higher mode effects are significant or local plastic mechanisms occur. In these cases, the distribution of demands resulting from the seismic response of the equivalent SDOF system cannot reproduce accurately local demands occurring in the actual MDOF system. The importance of these so-called "MDOF effects" increases with the amount of inelasticity and the worsening of the collapse mechanism typology of the structure and when the fundamental period of the structure exceeds approximately twice the characteristic site period. In this case, the fundamental period falls in the constant-velocity portion of the response spectrum and therefore higher mode contributions become more significant. Both CM and CSM have been found to provide quite different estimates of the target displacement for the same ground motion and the same building (Akkar and Metin [13], Chopra and Goel [14], Goel [15], Miranda and Ruiz-Garcia [16]) and improved procedures have been proposed for estimating the target displacement. In order to overcome such inconsistencies, the recently released FEMA-440 document (ATC-55) re-examined the existing NSPs and proposed improvements to both procedures for displacement modification (CM) and procedures for equivalent linearization (CSM). In particular, the Coefficient Method of FEMA 356 has been modified using improved relationships for coefficients $\mathrm{C}_{1}$ and $\mathrm{C}_{2}$ and replacing the coefficient $\mathrm{C}_{3}$ with a limitation to the minimum strength to avoid dynamic instability due to strength degradation and Pdelta effects. The equivalent linearization procedures have been modified leading to improved estimates of equivalent period and damping and an adjustment has been introduced to generate a Modified Acceleration-Displacement Response Spectrum (MADRS) that does intersect the capacity spectrum at the Performance Point. Recently, the capacity spectrum method of ATC-40 has been adopted as a seismic evaluation method in the Japanese structural design code and the nonlinear static $\mathrm{N} 2$ method [17] has been implemented in both Eurocode-8 [9] and in Italian Seismic Code [10].

\section{ADAPTIVE AND MULTIMODAL NONLINEAR STATIC PROCEDURES}

Generally, using modal properties of the structure in nonlinear static analysis is the most accessible approach to take into account the dynamic characteristics of the system. However, the conventional nonlinear static procedures are based on the assumption that the structure vibrates predominantly in a single mode and that the dynamic properties of the structure remain unchanged. The first assumption is not always fulfilled, especially in the case of high-rise buildings and/or torsionally flexible plan-asymmetric buildings. Furthermore, the progressive changes in the modal properties due to structural yielding are generally neglected. In order to include the effects of higher modes, some advanced modal pushover procedures based on the elastic modal decomposition concepts have been developed in literature. Many of these procedures consider higher modes in lateral load pattern in order to take into account higher mode effects both in plan and in elevation [18-23]. In particular, in the well-known modal pushover analysis (MPA) proposed by Chopra and Goel [18] higher mode effects are considered by analysing each mode as an equivalent single-degree-of-freedom system including nonlinear properties related to that mode. Multiple pushover analyses are conducted separately and then the total seismic response is estimated by combining the responses due to each modal load. Some authors have observed that while the first mode contribution requires a nonlinear analysis to be determined, the effect of higher modes may be estimated by linear analysis. Kunnath [24] investigated simple modal combination schemes to indirectly account for higher-mode effects. In order to take into account higher-mode effects, Poursha et al. [25] proposed the consecutive modal pushover (CMP) procedure that employs multi-stage and single-stage pushover analyses. In the multi-stage pushover analyses, modal pushover analyses are conducted consecutively with force distributions, using mode-shapes derived from the eigen-analysis of the linearly elastic structure. The seismic demands are then determined by enveloping the peak responses resulting from the multi-stage and single-stage pushover analyses.

The second main problem of conventional nonlinear static procedures is that they are based on the assumption that the mode shape remains unchanged after the structure yields. In order to overcome this drawback in recent years some adaptive pushover methods have been proposed to include the effects of higher modes and the changes in vibration characteristics due to the inelastic response. In particular, in order to include the changes in the dynamic properties of the structure Gupta and Kunnath [26] proposed an adaptive pushover procedure based on an elastic demand spectrum. In this procedure, conventional response spectrum analysis is essentially applied at each pushover step. Aydinoglu [27] developed an "incremental response spectrum 
analysis" (IRSA) in which, whenever a new plastic hinge takes place, elastic modal spectrum analysis is executed. Kalkan and Kunnath [28] proposed a new pushover analysis procedure derived through adaptive modal combinations (AMC) that accounts for the effects of both higher modes and varying dynamic characteristics due to inelastic response. Jianmeng et al. [29] proposed an improved MPA procedure to estimate the seismic demands of structures, considering the redistribution of inertia forces after the structure yields. Antoniou and Pinho [30] proposed an innovative displacement-based adaptive pushover (DAP) procedure, in which a set of laterally applied displacements, rather than forces, is monotonically applied to the structure. A modal analysis is performed step by step to update the displacement modal ratios during the process according to modal properties, softening of the structure, its period increase and the modification of inertial forces due to spectral amplification. The lateral displacement profiles of each vibration mode are combined by using SRSS or CQC method. An incremental updating with increment of displacement calculated according to the spectrum scaling is applied at each analysis step. Two shortcomings of the modal combination rules can be pointed out: the first one is that the result obtained does not fulfil equilibrium; the second limitation is that signs are lost during the combination process eliminating the contribution of negative quantities and considering an "always-additive" contribution of higher modes. Also, a solution is not provided to determine the target displacement in the adaptive nonlinear static analysis.

In spite of their deep theoretical background, many of the aforementioned methods suffer from the quadratic modal combination rules, in which the change in the sign of storey components at higher modes are removed as the sign reversals of load vectors in higher modes are neglected. Consequently, the magnitudes of the applied loads in all storey levels are positive. This inappropriate always-additive inclusion of higher mode contribution through a non-weighted SRSS combination rule represents a further weakness of modal pushover procedures. In the end, it is should be observed that all the multi-run methods, whether in an adaptive or non-adaptive form, are not able to reflect the interaction between modes in the nonlinear range. Furthermore, both SRSS or CQC combination rules are valid to combine the responses of independent modes and, strictly speaking, this assumption is no longer valid in the inelastic domain.

\section{EVALUATION OF ADVANCED METHODS FOR NONLINEAR STATIC ANALYSIS}

\subsection{Nonlinear Static Procedures}

The effectiveness and accuracy of the approximated analysis algorithms are verified through an extensive comparative study involving four nonlinear static procedures: a) N2-EXT: Extended N2 method considering higher mode effects both in plan and in elevation [17]; b) MMPA: Modified Modal Pushover Analysis procedure assuming higher modes as elastic [31]; c) ACSM1: Adaptive Capacity Spectrum Method based on Inelastic Demand Response Spectrum [32]; d) ACSM2: Adaptive Capacity Spectrum Method based on high damping modified acceleration-displacement response spectrum (MADRS) [33].
The extended N2 method (N2-EXT) is based on the assumption that the structure remains in the elastic range when vibrating at higher modes. The seismic demand in terms of displacements and storey drift is obtained by combining the results of basic pushover analysis and those of standard elastic modal analysis, by using correction factors taking into account both torsional and higher mode effects at upper storeys. The modified version of the MPA (Modified Modal Procedure Analysis MMPA) calculates the first mode contribution by nonlinear static analysis, whereas the effect of higher modes is estimated by a response spectrum analysis, assuming that the response of the structure subjected to higher mode load vectors remains in the elastic range. The mode effects on seismic demand are then combined using the CQC rule. ACSM1 is a displacement-based Adaptive Capacity Spectrum Method based on the inelastic demand response Spectra defined from $R-T$ relations [34]. In particular, the displacement-based adaptive pushover (DAP) procedure proposed by Antoniou and Pinho [30] is considered herein. The transformation from Capacity Curve $\left(\mathrm{V}-\delta_{\mathrm{TOP}}\right)$ to Capacity Spectrum $\left(\mathrm{S}_{\mathrm{a}}-\mathrm{S}_{\mathrm{d}}\right)$ in ADRS format (AccelerationDisplacement Response Spectra) is carried out step by step, as follows:

$$
\begin{gathered}
\Delta S_{a}^{i}=\Delta V^{i} \cdot \frac{\sum_{j=1}^{N} m_{j} \cdot \delta_{j}^{2}}{\left(\sum_{j=1}^{N} m_{j} \cdot \delta_{j}^{i}\right)^{2}} \\
\Delta S_{d}^{i}=\Delta \delta_{T O P}^{i} \frac{1}{\delta_{N}^{i}} \frac{\sum_{j=1}^{N} m_{j} \cdot \delta_{j}^{2}}{\sum_{j=1}^{N} m_{j} \cdot \delta_{j}^{i}}
\end{gathered}
$$

where $\Delta V^{i}$ and $\Delta \delta_{T O P}^{i}$ are the base shear increment and the corresponding roof displacement increment at the $i^{\text {th }}$ step of pushover analysis, $m_{j}$ is the mass of the $\mathrm{j}^{\text {th }}$ storey, $\delta_{j}^{i}$ is the lateral displacement of the $\mathrm{j}^{\text {th }}$ storey at the $\mathrm{i}^{\text {th }}$ step of pushover analysis, $\mathrm{N}$ is the number of storeys. Seismic demand is represented through Inelastic Demand Response Spectra (IDRS), that are indirectly computed scaling the 5\% damped Elastic Demand Response Spectra (EDRS) by the $R-T$ relations available in literature for the strength reduction factor [34]. ACSM2 is a methodology inspired by the CSM approach but reformulated within an "adaptive" framework. The adaptive capacity curve is intersected with an appropriately over-damped response spectrum (high damping modified acceleration-displacement response spectrum MADRS), thus providing an estimate of the inelastic acceleration and displacement demand on the structure [33].

\subsection{Structural Models}

A number of steel moment-resisting frames, that according to the Italian Code [10] are classified as either regular or irregular for seismic-resistant design purposes, have been considered in the numerical analyses (Fig. 1, Table 1). In particular, the four procedures outlined in the previous paragraph, namely N2-EXT, MMPA, ACSM1 and ACSM2, have been applied to six steel moment-resisting frames (three regular and three irregular in elevation): 1) 5-storey, 3-bay (5S3B); 2) 7-storey, 3-bay (7S3B); 3) 9-storey, 3-bay (9S3B). The frames have been designed to meet seismic 

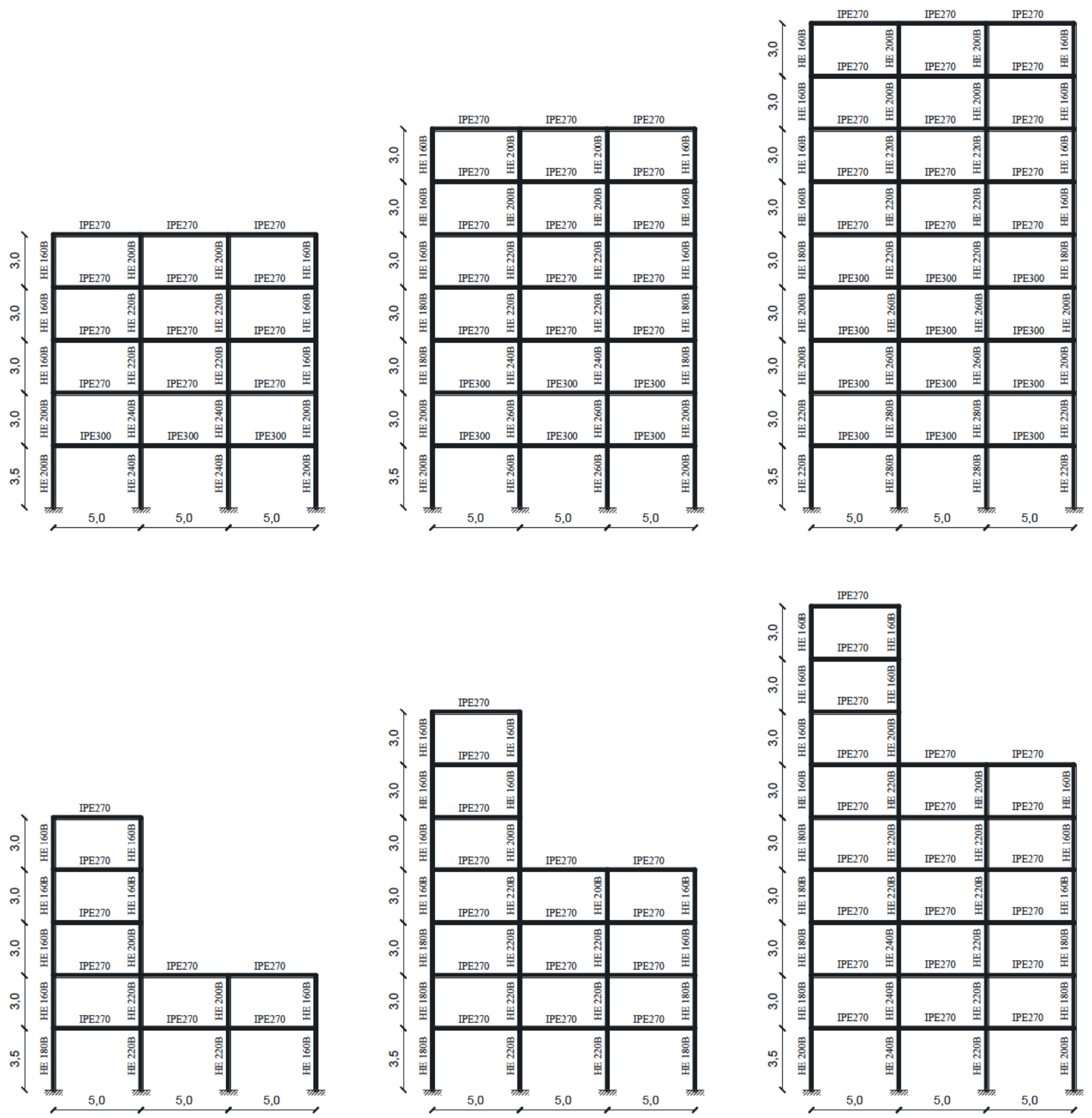

Fig. (1). Cases studies: regular and irregular moment resisting frames.

requirements of Italian Code [10]. The design seismic action has been defined assuming soil class $\mathrm{A}$, damping ratio $\xi=5 \%$, peak ground acceleration $\mathrm{PGA}=0.25 \mathrm{~g}$, behaviour factor $\mathrm{q}=6.5$ for regular frames and $\mathrm{q}=6.5 \times 0.80=5.2$ for irregular frames. Steel members are made of S275 steel grade $(f y=275 \mathrm{MPa})$. The interstorey height is $3.5 \mathrm{~m}$ for the first floor and $3.0 \mathrm{~m}$ for the upper floors. The bay length is $5.0 \mathrm{~m}$. The natural periods and the modal mass ratios of the first three mode shapes are reported in (Table 2). Two drift criteria are considered in the design. The first one is applied to the serviceability limit state and bounds the interstorey deflection normalized to the storey height to 0.01 for buildings without non-structural elements or having non-structural elements connected in such a way to not interfere with structural deformations. A second limit on the maximum permissible interstorey drift is applied to the ultimate limit state and is defined by using the stability coefficient, which is found in connection with P-delta actions. According to EC8 (4.4.2) [9] and NTC08 (7.3.1) [10] the value of the coefficient $\theta$ shall not exceed 0.3 . In practice this value is seldom critical, which is why, according to EC8 and NTC08, greater drifts can be tolerated by the structure if compared to the interstorey drift limit 0.02 suggested in other building codes, such as $\mathrm{UBC}$ [35]. In this paper, the design has been carried out so 
Table 1. Dimensions of structural members in steel frames.

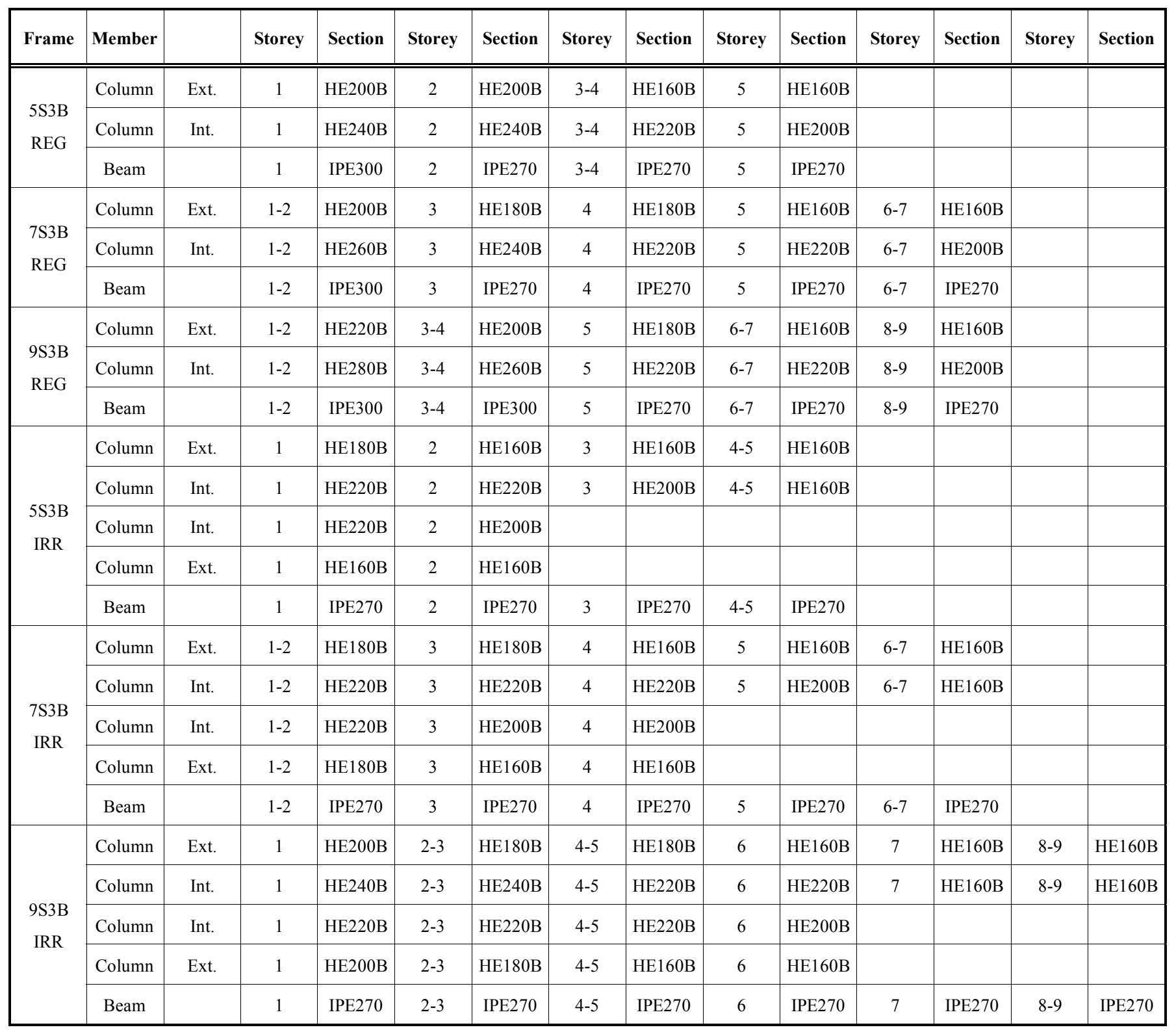

that the coefficient $\theta$ does not exceed 0.20 . In the cases where $0.1<\theta \leq 0.2$ the second-order effects are approximately taken into account by multiplying the seismic action effects by a factor equal to $1 /(1-\theta)$ suggested in Eurocode 8 [9]. The limit $\theta \leq 0.2$ on the maximum permissible interstorey drift is critical for all the regular steel moment-resisting frames. On the contrary, for the irregular steel frames the design solution is governed by the capacity design rules. In (Table 1) are reported the design solutions resulted from the verification of both drift criteria and design rules.

Finally, the instability-free feature has been checked against the provisions given in both Eurocode 3 [36] and Italian Code [10]. Limiting the value of the normalised axial load in the columns to 0.30 helped to prevent the analysed frames from possible problems of global instability, as these would have impaired an accurate calculation of the nonlinear response [37].
A distributed plasticity-fibre element model implemented in the SeismoStruct computer code [38] has been used in nonlinear analyses. Sources of geometrical nonlinearity taken into account are both local and global. The spread of plasticity along the member is represented by means of an inelastic cubic formulation with two Gauss points. A bilinear Kinematic Hardening material model has been used for steel. The assumptions regarding the design of beam-to-column joints permit to avoid the modelling of web panel. In fact, according to FEMA 356 [8] this modelling may be avoided if the expected shear strength of panel zones exceeds the flexural strength of the beams at beam-to-column connections and the stiffness of the panel zone is over 10 times larger than the flexural stiffness of the beam. Consequently, rigid full strength beam-to-column joints have been assumed in the analyses. All sources of geometrical nonlinearity, however, have been considered in the analysis, namely $P$ delta and large displacement effects. 
The accuracy of abovementioned procedures is evaluated by comparing their predictions with estimates obtained from a comprehensive set of nonlinear response history analyses (RHA). To this aim, a set of 7 input ground motions have been selected in such a way to be consistent with $5 \%$ damped Eurocode 8 type 1 elastic spectrum for soil class A [9]. The parameters of these earthquake ground motions are shown in (Table 3), where $M_{w}$ is the moment magnitude. The records are available in the European Strong-motion Database site (http://www.isesd.hi.is) as well as in Simbad Database [39]. The earthquake recordings have been adjusted to obtain spectrum-compatible accelerograms using SeismoMatch software [40]. In Fig. (2) the spectral acceleration of the accelerograms adjusted to match the selected target response spectrum are reported. Different levels of peak ground accelerations are considered in the analyses (PGA $=0.2 \mathrm{~g}, 0.4 \mathrm{~g}, 0.6 \mathrm{~g}, 0.8 \mathrm{~g}$ ). Different levels of damping have been considered in the analyses for different peak ground accelerations. In particular, $\xi=2 \%$ of critical damping has been considered for $\mathrm{PGA}=0.2 \mathrm{~g}, \xi=3 \%$ for $\mathrm{PGA}=0.4 \mathrm{~g}$, $\xi=4 \%$ for $\mathrm{PGA}=0.6 \mathrm{~g}$ and $\mathrm{PGA}=0.80 \mathrm{~g}$.

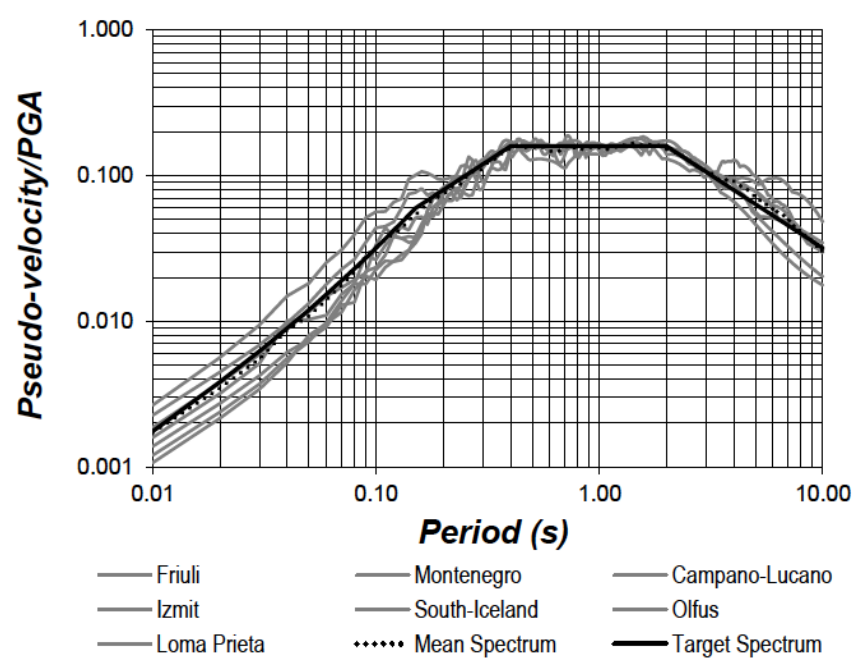

Fig. (2). Pseudo-velocity response spectra of accelerograms adjusted to match target response spectrum.

\subsection{Total Drift Ratio}

At first, the accuracy in prediction of peak inelastic drift response has been evaluated by comparing predictions using the NSPs with estimates obtained from the set of nonlinear time-history analyses. Comparisons have been carried out in terms of total drift ratio, that is the top floor lateral displacement divided by the building height. In Fig. (3) the scatter plot comparing total drift ratio from NSP and RHA is shown. In particular, the numerical model of each structural frame has been subjected to the adjusted selected accelerograms scaled to the peak ground acceleration $\mathrm{PGA}=0.20 \mathrm{~g} ; 0.40 \mathrm{~g}$; $0.60 \mathrm{~g} ; 0.80 \mathrm{~g}$. The mean of target roof displacements resulted from the pushover methods for the seven considered records have been compared with the mean of maximum target displacements resulted from RHA under the seven considered records. All the NSPs tend to greatly underestimate the target displacement for $\mathrm{PGA}=0.20 \mathrm{~g}$. In this case, all the framed structures respond elastically and, thus, the elastic demand response spectrum have been used for all modes in the CSM framework. Consequently, the adaptive pushover procedures turn into conventional pushover procedures under invariant lateral force distribution. Therefore, in this case the differences between NSPs and RHA are not dependent on the inelasticity in the structure, but entirely arise from the analysis methods (Linear Static Analysis under invariant load pattern for N2-EXT, ACSM1, ACSM2; Linear Modal Analysis for MMPA) that overestimate the roof drift compared to Direct Integration Time History Analysis. For all values of the variable PGA between $0.40 \mathrm{~g}$ and $0.80 \mathrm{~g}$, all the NSPs generally overestimate the total drift and the scatter between static and dynamic response increases. In these cases, the amount of inelasticity in the structure increases and the distribution of localized demands in the MDOF system can significantly differ from those associated to the equivalent SDOF system. These so-called MDOF effects increase the error in predicting inelastic dynamic response. The comparison between NSPs using invariant lateral load patterns (N2-EXT, MMPA) and adaptive pushover procedures (ACSM1, ACSM2) reveals that both methods generally overestimate the target displacement, but in many cases a great underestimation of the inelastic response is observed, and this leads to nonconservative estimates of the response.

\subsection{Storey Displacement Profiles}

A good estimation of storey displacement profiles as well as of inter-storey drift profiles is a critical parameter in seismic evaluation. In Figs. $(4,5)$ the profiles of storey displacement divided by total height relative to base are plotted against the storey level for regular and irregular frames, respectively. In particular, the mean of the interstorey drifts resulting from all of the seven records are reported. For $P G A=0.20 \mathrm{~g}$ all the NSPs tend to greatly underestimate the total drift of each floor both for regular and irregular frames. This result is an effect of overestimation of the target displacement. On the contrary, the total drift profiles from NSPs and RHA are very similar. When the PGA increases in the range $[0.40 \mathrm{~g}-0.80 \mathrm{~g}]$, that is when the amount of inelasticity in the structure increases, the total drift profile becomes more dependent on the considered pushover procedure. In particular, the adaptive NSPs (ACSM1, ACSM2) tend to give better estimations in the lower storeys, while the NSPs based on invariant load pattern (N2-EXT, MMPA) tend to overestimate the total drift in the lower storeys. This result derives from the occurrence of local plastic mechanisms in the lower storeys which are strongly dependent on the lateral force distribution used in N2-EXT and in MMPA for the first mode contribution. These mechanism do not take place neither in RHA nor in adaptive pushover procedures that, consequently, give better estimation of total drift profiles. On the contrary, in the upper storeys the total drift profile of RHA is better estimated by N2-EXT and MMPA. For all the structures here examined the fundamental periods fall in the constant-velocity portion of the response spectrum and so higher-mode contributions become more significant. In this case, the correction factors taking into account higher mode effects for N2-EXT method and the elastic higher mode contribution for MMPA seem to be more effective in the estimation of total drift profiles in the upper storeys.

\subsection{Interstorey Drift Profiles}

In Figs. $(6,7)$ the interstorey drift profiles resulting from NSPs and RHA are shown for regular and irregular steel 

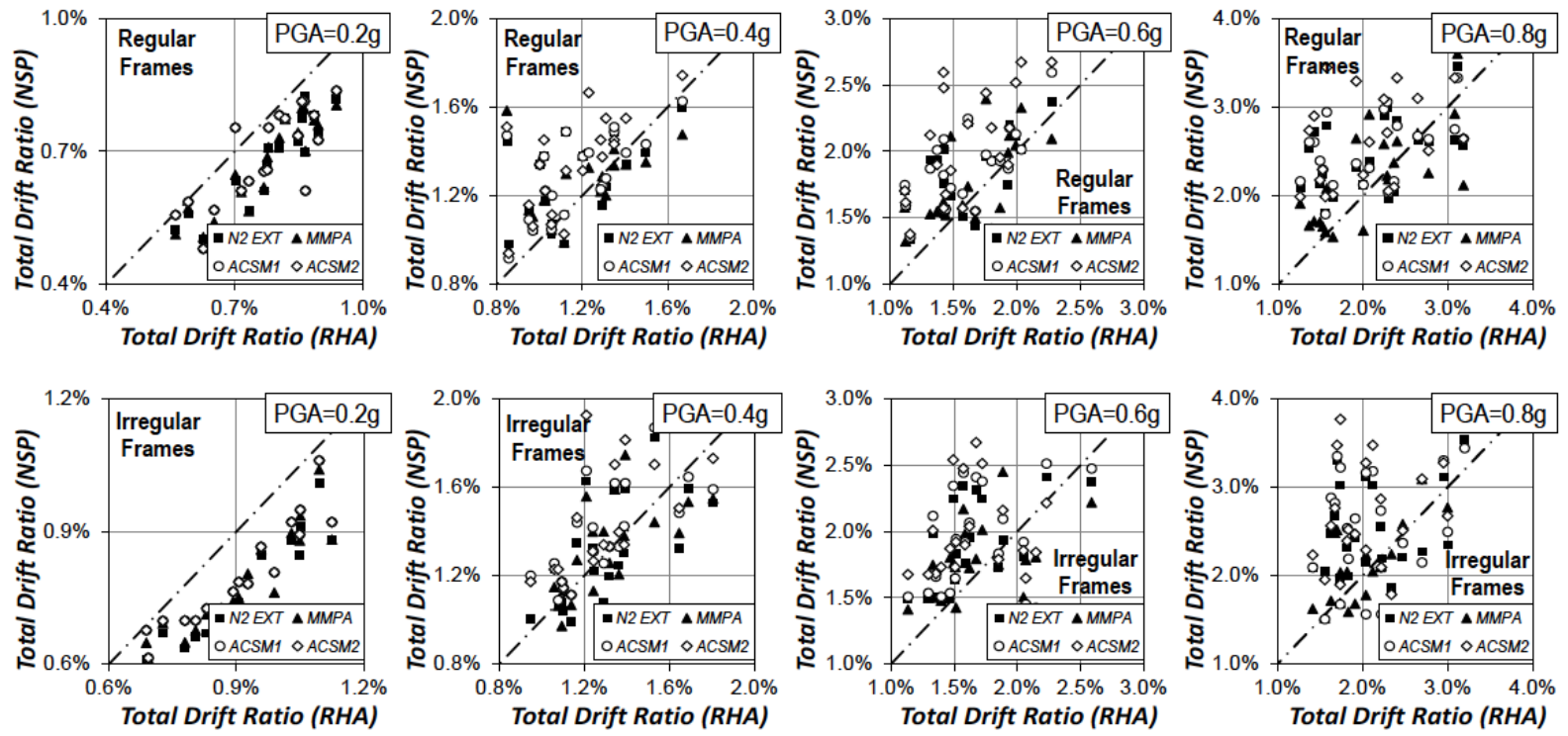

Fig. (3). Scatter plot comparing roof drift ratio from NSP and RHA.

Table 2. Modal periods and mass ratios of analysed frames.

\begin{tabular}{|c|c|c|c|c|c|c|c|c|c|c|c|c|}
\hline & \multicolumn{9}{|c|}{ Regular Frames } & \multicolumn{5}{c|}{ Irregular Frames } \\
\hline Frame & $\mathbf{T}_{\mathbf{1}}(\mathbf{s})$ & $\mathbf{T}_{\mathbf{2}}(\mathbf{s})$ & $\mathbf{T}_{\mathbf{3}}(\mathbf{s})$ & $\boldsymbol{\alpha}_{\mathbf{1}}$ & $\boldsymbol{\alpha}_{\mathbf{2}}$ & $\boldsymbol{\alpha}_{\mathbf{3}}$ & $\mathbf{T}_{\mathbf{1}}(\mathbf{s})$ & $\mathbf{T}_{\mathbf{2}}(\mathbf{s})$ & $\mathbf{T}_{\mathbf{3}}(\mathbf{s})$ & $\boldsymbol{\alpha}_{\mathbf{1}}$ & $\boldsymbol{\alpha}_{\mathbf{2}}$ & $\boldsymbol{\alpha}_{3}$ \\
\hline \hline 5S3B & 1.507 & 0.515 & 0.309 & 0.821 & 0.120 & 0.048 & 1.305 & 0.623 & 0.333 & 0.671 & 0.404 & 0.031 \\
\hline 7S3B & 2.015 & 0.691 & 0.401 & 0.795 & 0.122 & 0.044 & 1.761 & 0.847 & 0.431 & 0.780 & 0.123 & 0.128 \\
\hline 9S3B & 2.441 & 0.868 & 0.500 & 0.778 & 0.129 & 0.038 & 2.280 & 0.983 & 0.587 & 0.801 & 0.081 & 0.064 \\
\hline
\end{tabular}
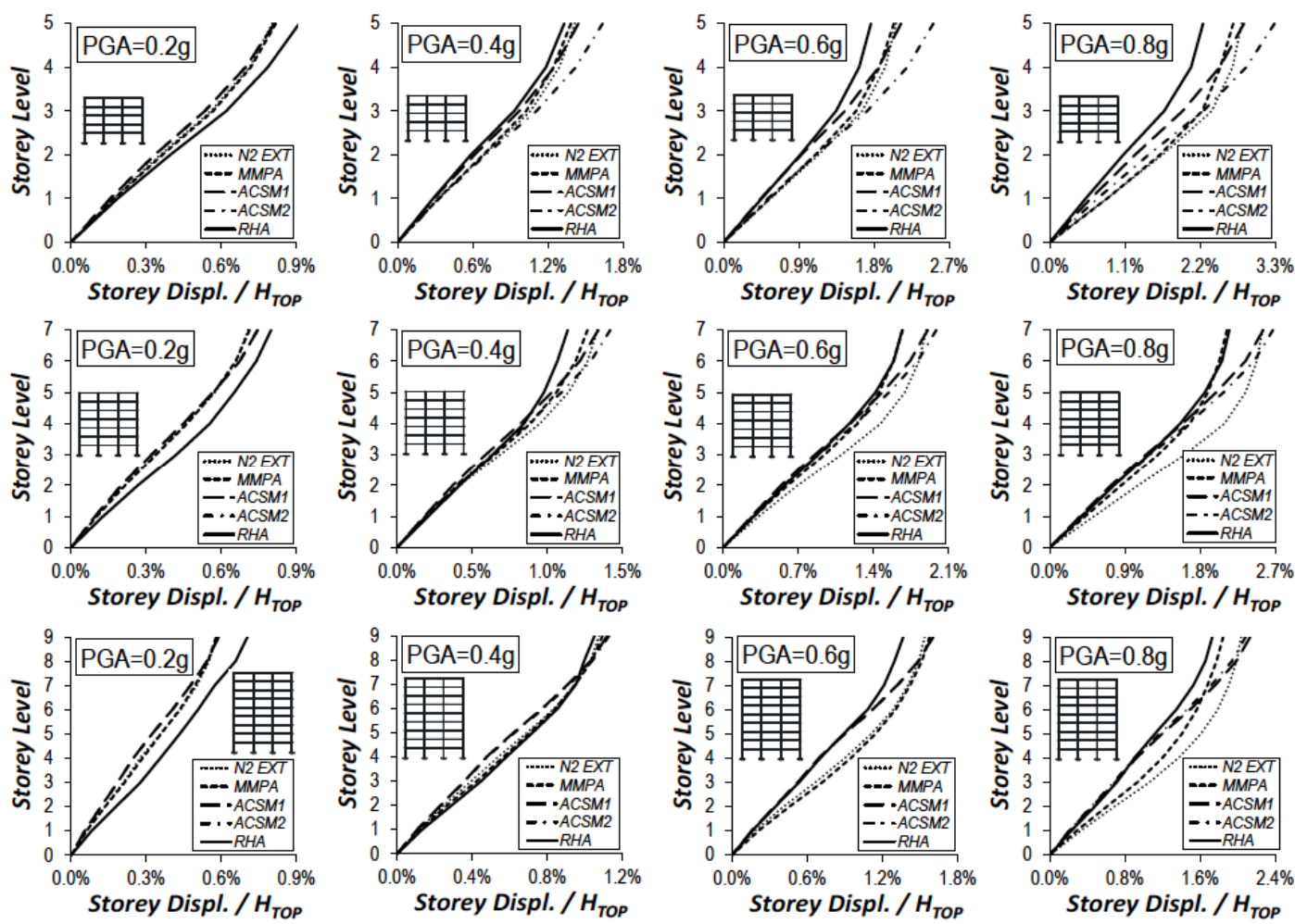

Fig. (4). Mean storey displacement profiles resulting from NSPs and RHA (Regular steel frames). 
Table 3. Parameters of earthquake ground motions.

\begin{tabular}{|c|c|c|c|c|c|c|}
\hline Input & Station ID & Date & Time & Dir. & PGA (m/s $\mathbf{s}^{2}$ & $\mathbf{M}_{\mathbf{w}}$ \\
\hline \hline Friuli & ST20 & $06 / 05 / 1976$ & $20: 00$ & NS & 3,499 \\
\hline Montenegro & ST64 & $15 / 04 / 1979$ & $06: 11$ & EW & 2,199 \\
\hline Campano Lucano & ST93 & $23 / 11 / 1980$ & $18: 34$ & NS & 1,363 & 6,9 \\
\hline Izmit & ST575 & $17 / 08 / 1999$ & $00: 01$ & NS & 1,576 & 7,6 \\
\hline South Iceland & ST108 & $17 / 06 / 2000$ & $15: 40$ & NS & 6,238 & 6,439 \\
\hline Olfus & ST101 & $29 / 05 / 2008$ & $15: 45$ & EW & 6,3 \\
\hline Loma Prieta & ST47379 & $18 / 10 / 1989$ & $00: 04$ & NS & 6,029 & 6,9 \\
\hline
\end{tabular}
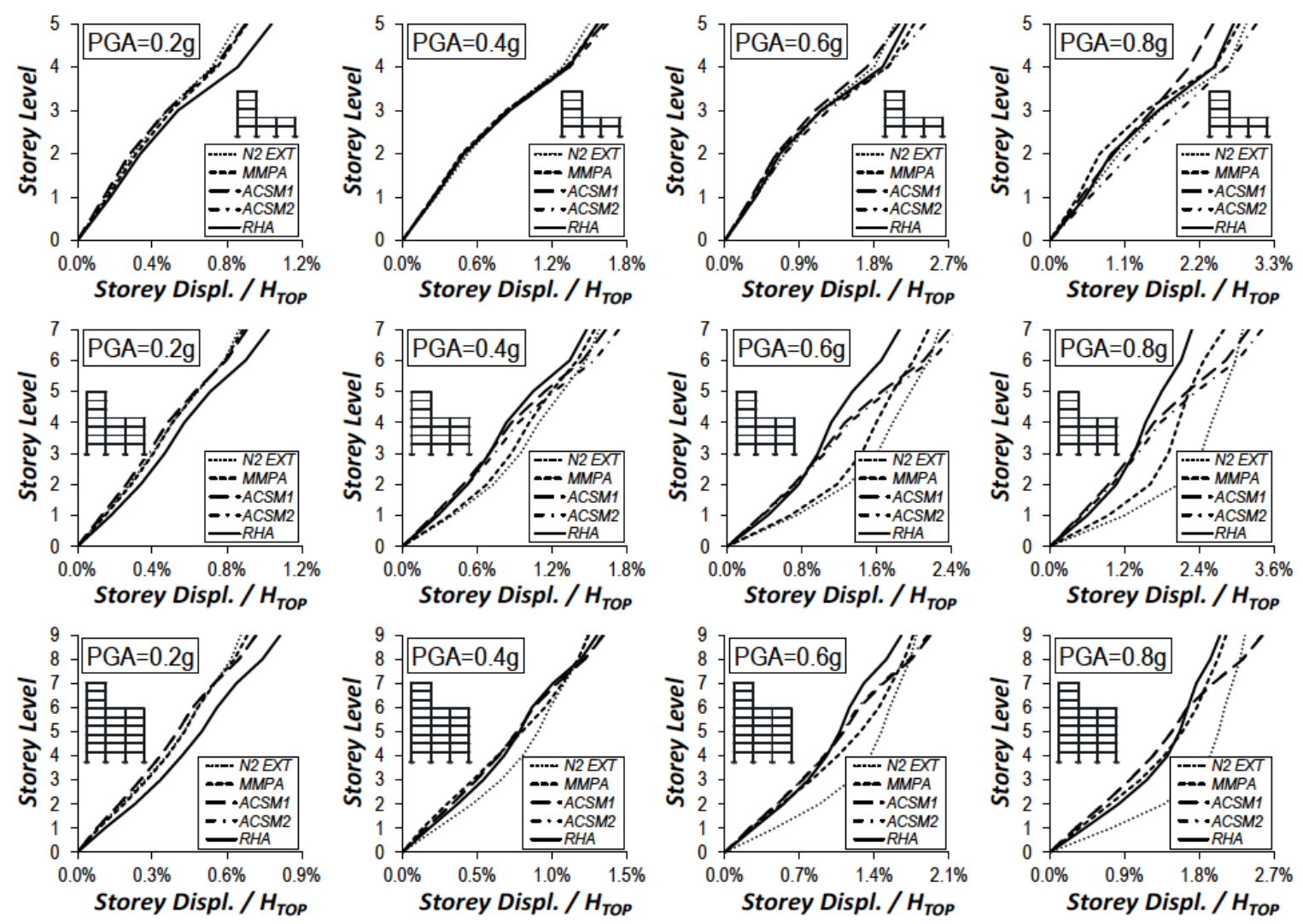

Fig. (5). Mean storey displacement profiles resulting from NSPs and RHA (Irregular steel frames).

frames, respectively. In particular, the mean of the interstorey drifts resulting from the seven earthquake ground motions is reported. In the same figures the error of the mean interstorey drift coming from the different NSPs with respect to the mean interstorey drift of the RHA analysis is plotted. In particular, the error of each pushover procedure in predicting the interstorey drift has been calculated by the following equation:

$$
\operatorname{Error}(\%)=100 \times \frac{\bar{\Delta}_{i, N S P}-\bar{\Delta}_{i, R H A}}{\bar{\Delta}_{i, R H A}}
$$

where $\bar{\Delta}_{i, R H A}$ is the mean of maximum interstorey drift of $i^{\text {th }}$ storey resulting from RHA under the seven considered re- cords and $\bar{\Delta}_{i, N S P}$ is the mean of interstorey drift of $i^{\text {th }}$ storey in the considered NSP at the target displacement.

The resulting interstorey drift profiles show that, in general, the accuracy of ACSM1 and ACSM2 procedures is better in the lower storey levels where the effects of higher modes are lower. On the contrary, considerable underperformance is obtained in the upper storey levels, and this deficit increases with the PGA. The drift profiles of MMPA and N2-EXT are significantly enhanced by the combination of results of pushover analysis and elastic modal analysis. In particular, the correction factors used in N2-EXT method to approach the higher mode problem significantly improve the coherence between NSPs and RHA in terms of drift profile 

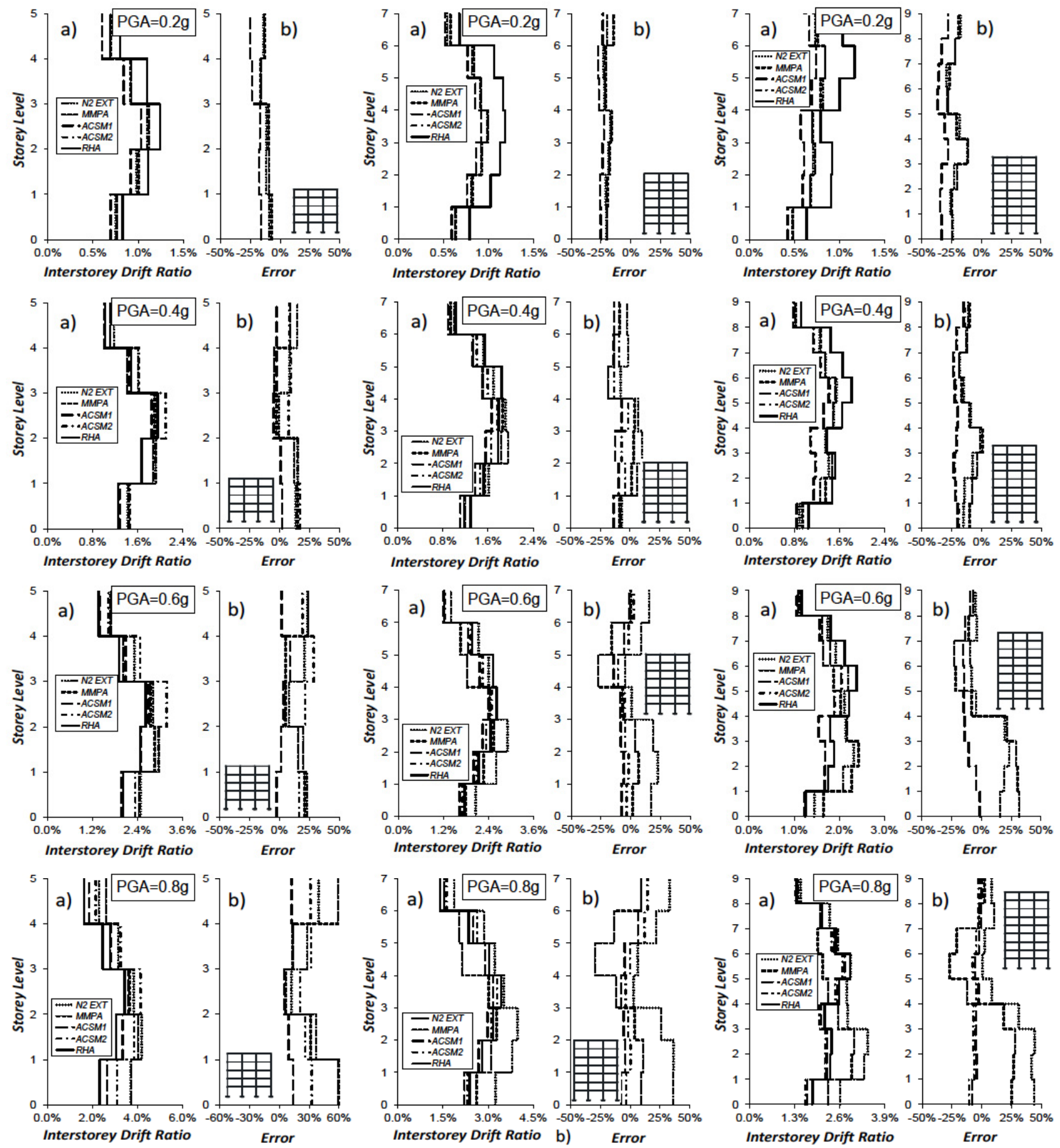

Fig. (6). a) Mean interstorey drift profiles resulting from NSPs and RHA for regular steel frames; b) Error of the mean interstorey drift of the different NSPs with respect to the mean interstorey drift of the RHA analysis.

in the upper stories. However, the N2-EXT method tends to overestimate the interstorey drifts in the lower storey, especially for the irregular and the higher frame herein considered, and this overestimation tends to increase with the PGA. This result is a consequence of the local plastic mechanism in the lower storeys that only occurs in the N2-EXT pushover procedure.

For higher PGA levels ( $\mathrm{PGA}=0.6 \mathrm{~g}$ and $\mathrm{PGA}=0.8 \mathrm{~g}$ ) some differences in drift profiles between ACSM1 and ACSM2 have been found. These differences are independent of the bilinear representation of the capacity spectrum, but they entirely arise from the different prediction of seismic demands. In fact, ACSM1 uses inelastic demand response spectra defined from $\mathrm{R}-\mu-\mathrm{T}$ relations, while ACSM2 is based on high damping modified acceleration-displacement response spectrum (MADRS).

\subsection{Accuracy of NSPs}

In order to evaluate the accuracy of the mentioned approaches in predicting seismic demands, the results of 

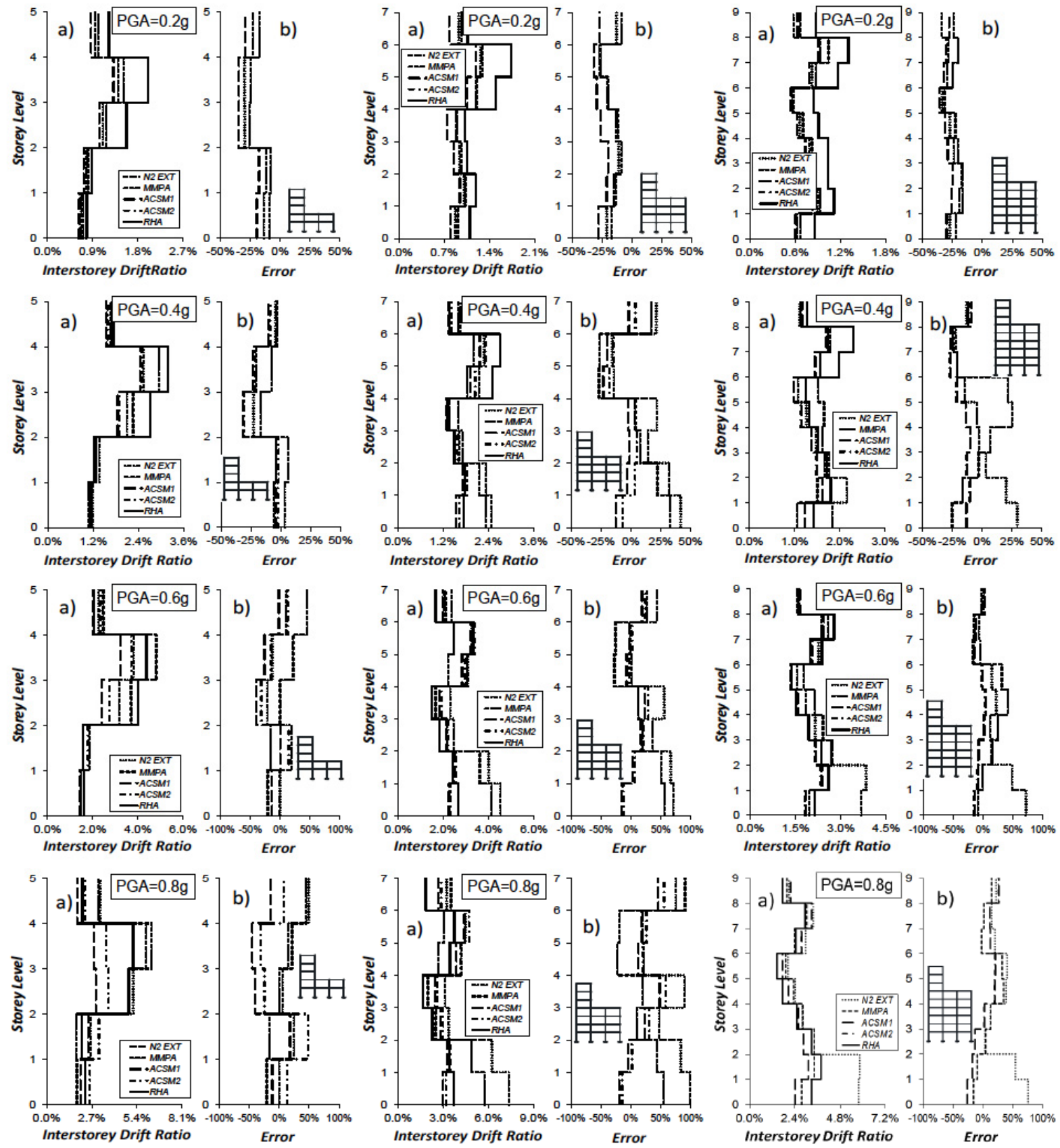

Fig. (7). a) Mean interstorey drift profiles resulting from NSPs and RHA for irregular steel frames; b) Error of the mean interstorey drift of the different NSPs with respect to the mean interstorey drift of the RHA analysis.

considered pushover procedures have been compared with nonlinear dynamic analysis assumed as a reference solution. To this aim, the total error of each pushover procedure on the interstorey drift profile has been defined as follows:

Total Error $(\%)=100 \times \sqrt{\frac{1}{N} \cdot \sum_{i=1}^{N}\left(\frac{\bar{\Delta}_{i, N S P}-\bar{\Delta}_{i, R H A}}{\bar{\Delta}_{i, R H A}}\right)^{2}}$

where $\mathrm{N}$ is the number of the storeys of the frame. In Fig. (8) the total error for regular and irregular frames is plotted as a function of peak ground acceleration. The results show that higher errors generally occur for $\mathrm{PGA}=0.20 \mathrm{~g}$ and for $P G A=0.8 \mathrm{~g}$. In the first case $(\mathrm{PGA}=0.20 \mathrm{~g})$, as previously stated, all frames respond elastically and the higher error of
NSPs compared with nonlinear dynamic analysis derives from the analysis method (Linear Static Analysis for N2EXT, ACSM1, ACSM2; Linear Modal Analysis for MMPA and Linear Time-history analysis for RHA). In the second case $(\mathrm{PGA}=0.80 \mathrm{~g})$, the use of NSPs based on invariant load pattern (N2-EXT, MMPA) generally implies more significant errors than in the case of adaptive pushover procedures, especially for the higher frames. As said before, this result comes from the overestimation of interstorey drift in the lower storeys obtained applying the NSPs based on invariant load patterns. The N2-EXT method produces higher errorrate when compared with the other NSPs, and this error tends to increase with peak ground acceleration and irregularity in the structure. 

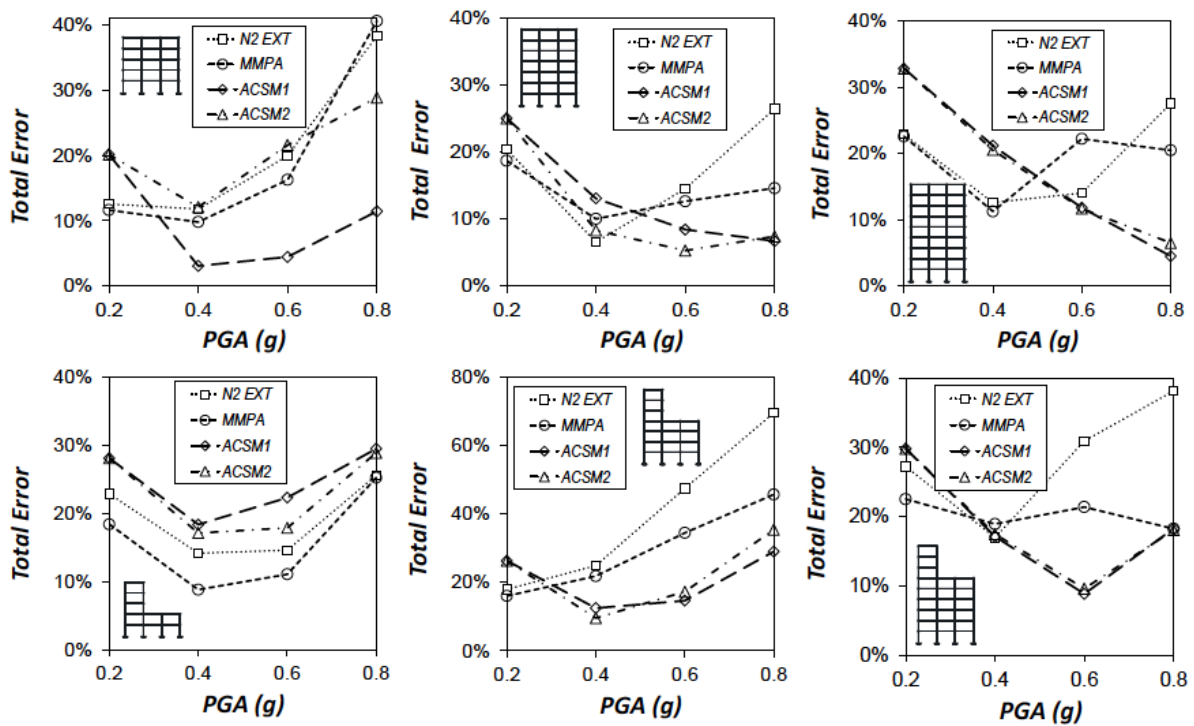

Fig. (8). Total error of the mean interstorey drift of the NSPs with respect to the mean interstorey drift of the RHA.
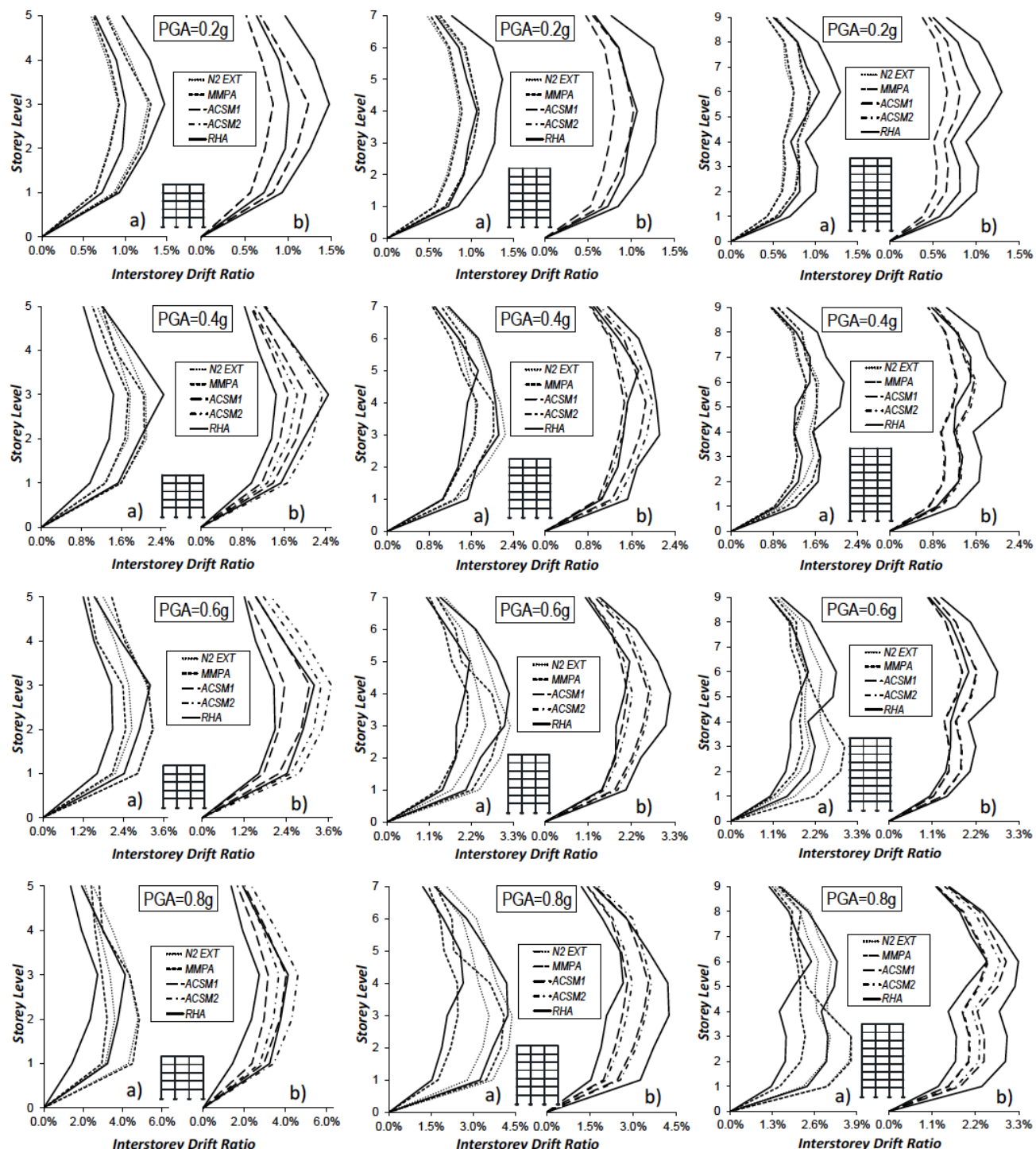

Fig. (9). Mean + Standard deviations and Mean - Standard deviations of the interstorey drift resulting from the records. Comparison between the different NSPs and the RHA analysis (Regular Frames). 

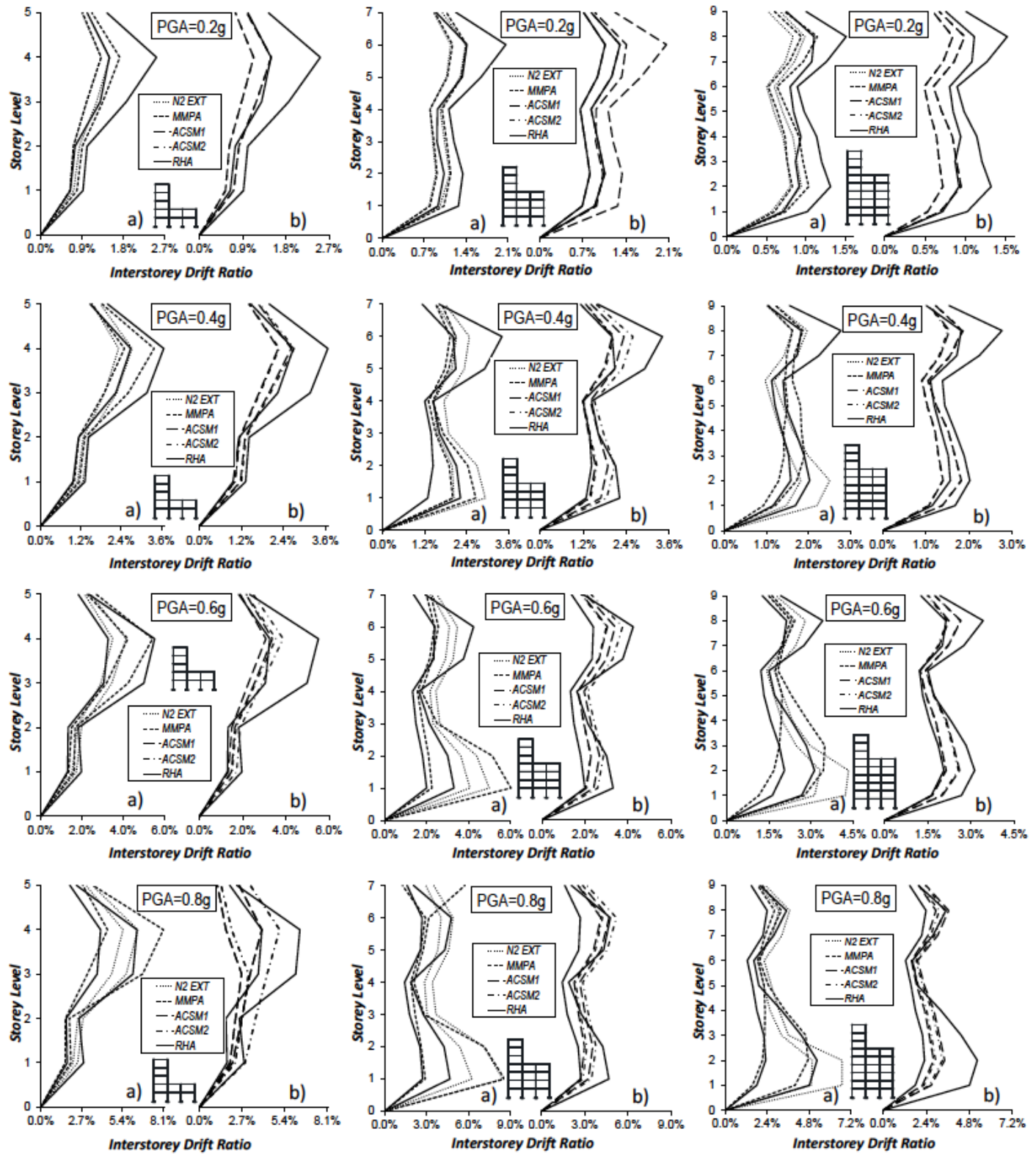

Fig. (10). Mean + Standard deviations and Mean - Standard deviations of the interstorey drift resulting from the records. Comparison between the different NSPs and the RHA analysis (Irregular Frames).

\subsection{Sensitivity to Earthquake Ground Motion}

The sensitivity of the structural response to the specific characteristics of earthquake ground motions have been finally evaluated. For this purpose, the Mean \pm Standard deviations interstorey drift profiles (16 and 84 percentiles) resulting from all records are plotted in Figs. $(\mathbf{9}, \mathbf{1 0})$, for regular and irregular frames, respectively. The interstorey drift profiles obtained from the NSPs have been compared with the corresponding profiles resulting from the RHA analyses. In particular, in Figs. (9a and 10a) the interstorey drift profiles obtained from the pushover procedures with invariant lateral load patterns are shown, whereas in Figs. (9b and 10b) the interstorey drift profiles obtained from the adaptive pushover procedures are plotted. The adaptive NSPs exhibit a scattering of results lower than RHA and, consequently, data points tend to be closer to the mean. This difference increases with the amount of inelasticity in the structure, that is with the peak ground acceleration. On the contrary, the NSPs based on invariant lateral load patterns tend to have a measure of scatter comparable with RHA, especially for the highest values of PGA examined herein $(\mathrm{PGA}=0.6 \mathrm{~g}$; $\mathrm{PGA}=0.8 \mathrm{~g}$ ). Only for the irregular 7S3B and for the highest values of PGA the MMPA tends to exhibit a standard deviation much greater than RHA. In this case, a large increase of standard deviation at both lower storey levels and roof levels is observed when compared with the corresponding standard deviation obtained from both other NSPs and RHA. This difference is only observed in lower storey levels and in roof level, whereas smaller standard deviations are observed for the intermediate levels. This is caused, in first place, by the sensitivity of the nonlinear response of the first mode in MMPA to the characteristics of the input ground motion, 
which result in greater standard deviations at both lower storey levels and roof level. At the intermediate levels the contribution of second and third mode, that is weakly dependent on the input ground motion, increases and, consequently, the standard deviation decreases.

\section{CONCLUSION}

Some advanced pushover procedures taking into account the frequency content of response spectra, higher mode effects, progressive changes in the modal properties due to structural yielding and interaction between modes in the inelastic range have been compared. Pushover methods accounting for higher mode effects along the elevation provide more accurate estimation of seismic demands when compared with traditional pushover methods based on load pattern using first mode. Although higher modes have been found to be significantly participating in the global dynamic behaviour of the structure, the estimation of their effect could be inadequate, especially at the lower storeys, if an invariant lateral load pattern is assumed in the analysis. The resulting interstorey drift profiles show that, in general, the accuracy of nonlinear static procedure based on invariant load patterns at the lower storey levels is worse, especially for higher or irregular frames. On the contrary, at the upper storey levels the accuracy is comparable with that obtained from adaptive procedures. This means that the effects of higher modes are well interpreted by correction factors proposed in the extended N2 method and by the elastic response spectrum superposition suggested in the modified version of the Modal Pushover Analysis. Eventually, adaptive nonlinear static procedures tend to have a less sensitive response to the input ground motion when compared to response history analysis and other pushover procedures based on invariant load patterns. This difference generally increases with the amount of inelasticity and irregularity present in the structure. On the contrary, the modified modal pushover analysis may give much sensitive response to the input ground motion, especially for irregular frames. Furthermore, the standard deviation of the interstorey drift estimate is often strongly variable with height.

\section{CONFLICT OF INTEREST}

The authors confirm that this article content has no conflict of interest.

\section{ACKNOWLEDGEMENTS}

The subject dealt with in this paper is a part of the research project RELUIS 2014-2018 "Steel and composite steel-concrete structures" (Coordinators Prof. R. Zandonini, Prof. R. Landolfo), issued by the Italian "Dipartimento della Protezione Civile". The activity described in the paper was carried out by the members of Research Unit of the Second University of Naples, coordinated by Prof. A. Mandara.

\section{REFERENCES}

[1] A. Longo, R. Montuori and V. Piluso, " Plastic design of seismic resistant V-braced frames", Journal of Earthquake Engineering, vol. 12, no. 8, pp. 1246-1266, 2008.
[2] A. Longo, R. Montuori and V. Piluso,"Failure mode control of Xbraced frames under seismicactions", Journal of Earthquake Engineering, vol. 12, no. 5, pp. 728-759, 2008.

[3] A. Longo, R. Montuori and V. Piluso, "Theory of plastic mechanism control of dissipative truss moment frames", Engineering Structures, vol. 37, pp. 63-75, 2012.

[4] R. Montuori, E. Nastri and V. Piluso, "Theory of plastic mechanism control for eccentrically braced frames with inverted Yscheme", Journal of Constructional Steel Research, vol. 92, pp. 122-135, 2014

[5] R. Montuori, E. Nastri and V. Piluso, "Theory of plastic mechanism control for the seismic design of braced frames equipped with friction dampers", Mechanics Research Communications, vol. 58, pp. 112-123, 2014.

[6] FEMA, NEHRP guidelines for the seismic rehabilitation of buildings, Report FEMA-273 (Guidelines) and Report FEMA-274 (Commentary), Washington (DC), 1997.

[7] ATC, Seismic Evaluation and Retrofit of Concrete Buildings, Report No. ATC-40, Applied Technology Council, Redwood City, CA, 1997.

[8] FEMA, Prestandard and Commentary for the Seismic Rehabilitation of Buildings, FEMA 356, prepared by the American Society of Civil Engineers for the Federal Emergency Management Agency. Washington, D.C, 2000.

[9] CEN, Eurocode 8: Design of structures for earthquake resistance, Part 1: general rules, seismic actions and rules for buildings, EN1998-1, European Committee for Standardization, 2004.

[10] Italian Code NTC08, Norme tecniche per le costruzioni in zone sismiche. Ministerial Decree D.M. 14.01.08, G.U. No.9-04.02.08 (in Italian), 2008.

[11] FEMA, Improvement of nonlinear static seismic analysis procedures, prepared by the Applied Technology Council (ATC-55 Project), FEMA 440, published by the Federal Emergency Management Agency, Washington, D.C., 2005.

[12] ASCE, Seismic Rehabilitation of existing buildings, ASCE/SEI 705, Published by the American Society of Civil Engineers, 2005.

[13] S. Akkar and A. Metin, "Assessment of Improved Nonlinear Static Procedures in FEMA-440", Journal of Structural Engineering, vol. 133, no. 9, pp. 1237-1246, 2007.

[14] A.K. Chopra and R.K. Goel, "Evaluation of NSP to Estimate Seismic Deformation: SDF Systems", Journal of Structural Engineering, vol. 126, no. 4, pp. 482-490, 2000.

[15] R.K. Goel, "Evaluation of Current Nonlinear Static Procedures Using Strong Motion Records", In: Proceedings of the 2007 Structures Congress, Long Beach, CA, American Society of Civil Engineers, Reston, VA. 2007.

[16] E. Miranda and J. Ruiz-Garcia, "Evaluation of approximate methods to estimate maximum inelastic displacement demands", Earthquake Engineering and Structural Dynamics, vol. 31, no. 3, pp. 539-560, 2002.

[17] M. Kreslin and P. Fajfar, "The extended N2 method considering higher mode effects in both plan and elevation", Bulletin of Earthquake Engineering, vol.10, pp. 695-715, 2012.

[18] A.K. Chopra and R.K. Goel, "A modal pushover analysis procedure for estimating seismic demands for buildings", Earthquake Engineering and Structural Dynamics, vol. 31, no. 3, pp. 561-582, 2002.

[19] A.K. Chopra and R.K. Goel, "A Modal pushover analysis procedure to estimate seismic demands for unsymmetric-plan buildings", Earthquake Engineering \& Structural Dynamics, vol. 33, pp. 903927, 2004.

[20] P. Fajfar, D. Marušić and I. Perus, "Torsional effects in the pushover-based seismic analysis of buildings", Journal of Earthquake Engineering, vol. 9, no. 6, pp. 831-854, 2005.

[21] R. Bento, C. Bhatt and R. Pinho, "Using nonlinear static procedures for seismic assessment of the 3D irregular SPEAR building", Earthquake and Structures, vol. 1, no. 2, pp. 177-195, 2010.

[22] J.C. Reyes and A. Chopra, "Three-dimensional modal pushover analysis of buildings subjected to two components of ground motion, including its evaluation for tall buildings", Earthquake Engineering and Structural Dynamics, vol.40, pp.789-806, 2011.

[23] E. Erduran, "Assessment of current nonlinear static procedures on the estimation of torsional effects in low-rise frame buildings", Engineering Structures, vol.30, 2548-2558, 2008. 
[24] S.K. Kunnath, "Identification of modal combination for nonlinear static analysis of building structures",Computer-Aided Civil and Infrastructure Engineering, vol.19, pp. 246-259, 2004.

[25] M. Poursha, F. Khoshnoudiana and A.S. Moghadam, "A consecutive modal pushover procedure for estimating the seismic demands of tall buildings", Engineering Structures, vol. 31, pp. 591-599, 2009.

[26] B. Gupta and S.K. Kunnath, "Adaptive spectra-based pushover procedure for seismic evaluation of structures", Earthquake Spectra, vol. 162, pp. 36-91, 2000.

[27] M.N. Aydinoglu, "An incremental response spectrum analysis procedure on inelastic spectral displacements for multi-mode seismic performance evaluation", Bulletin of Earthquake Engineering, vol. 1, pp. 3-36, 2003

[28] E. Kalkan and S.K. Kunnath, "Adaptive modal combination procedure for nonlinear static analysis of building structures", Journal of Structural Engineering, vol. 132, no. 11, pp. 1721-1731, 2006.

[29] M. Jianmeng, Z. Changhai and X. Lili, "An improved modal pushover analysis procedure for estimating seismic demands of structures", Earthquake Engineering \& Engineering Vibration, vol. 7, pp. 25-31, 2008.

[30] S. Antoniou and R. Pinho, "Development and verification of a displacement-based adaptive pushover procedure" Journal of Earthquake Engineering, vol. 8, no. 5, pp. 643-661, 2004.

[31] A.K. Chopra, R.K. Goel and C. Chintanapakdee, "Evaluation of a modified MPA procedure assuming higher modes as elastic to estimate seismic demands", Earthquake Spectra, vol. 20, no. 3, pp. 757-778, 2004.
[32] M. Ferraioli, A. Lavino, A.M. Avossa and A. Mandara, "Displacement-based seismic assessment of steel moment resisting frame structures" In: Proceedings of the $14^{\text {th }}$ World Conference on Earthquake Engineering, Beijing, China, October 12-17, 2008.

[33] R. Pinho and C. Casarotti, "Using the adaptive capacity spectrum method for seismic assessment of irregular frames", In: Proceedings of the $5^{\text {th }}$ European workshop on the seismic behaviour of irregular and complex structures. Catania, 2008.

[34] T. Vidic, P. Fajfar and M. Fischinger, "Consistent inelastic design spectra: strength and displacement", Earthquake Engineering and Structural Dynamics, vol. 23, pp. 502-521, 1994.

[35] UBC, Uniform Building Code, Vol. 2: Structural engineering design provisions, Whittier, CA, 1997.

[36] CEN. Eurocode 3: Design of steel structures. Part 1-1: General rules and rules for buildings. European Committee for Standardization, 2005.

[37] M. Ferraioli, A. Lavino and A. Mandara, "Behaviour factor of code-designed steel moment-resisting frames", International Journal of Steel Structures, vol. 14, no. 2, pp. 1-12, 2014.

[38] SeismoSoft, SeismoStruct: A computer program for static and dynamic analysis for framed structures, [Online] Available from URL: www.seismosoft.com, 2014.

[39] C. Smerzini and R. Paolucci, Simbad: a database with selected input motions for displacement-based assessment and design, Research Project DPC Reluis, 2013.

[40] SeismoSoft, SeismoMatch, [Online] Available from URL: www.seismosoft.com, 2014

(C) Ferraioli et al.; Licensee Bentham Open.

This is an open access article licensed under the terms of the Creative Commons Attribution Non-Commercial License (http://creativecommons.org/licenses/by-nc/3.0/) which permits unrestricted, non-commercial use, distribution and reproduction in any medium, provided the work is properly cited. 